This is the pre-peer reviewed version of the following article:

Heaven, S., Koloskov, G. B., Lock, A. C., Tanton, T. W. (2002) Water resources management in the Aral Basin: a river basin management model for the Syr Darya. Irrigation and Drainage, 51(2) 109-118.

DOI: $10.1002 /$ ird.42

which has been published in final form at http://onlinelibrary.wiley.com/doi/10.1002/ird.42/abstract.

\title{
Water Resources Management in the Aral Basin: a River Basin
}

\section{Management Model for the Syr Darya}

\author{
S. Heaven ${ }^{1}$, G. B. Koloskov ${ }^{2}$, A. C. Lock ${ }^{1}$, and T.W. Tanton ${ }^{1 \mathrm{a}}$ \\ ${ }^{1,1 a}$ Department of Civil and Environmental Engineering, University of Southampton, Southampton, SO17 1BJ, UK. \\ ${ }^{l a}$ is corresponding author, e-mail twt@ soton.ac.uk \\ ${ }^{2}$ BG Chair of Environmental Technology, Almaty Institute of Power Engineering and Telecommunications, 126 \\ Baytursynov Street, Almaty 480013, Kazakhstan.
}

Short title: Water Resources Management Model for the Syr Darya

\begin{abstract}
The Aral Sea environmental crisis has been created by poor water management in the river basins of the Amu Darya and Syr Darya. Nearly all the flow is abstracted for ailing irrigation schemes in the upper and middle basins, for massive river basin transfer schemes, or is lost to evaporation and seepage from reservoirs and canals. The only solution to the crisis in the lower deltas is to allow more water to flow to them. The paper argues that the only practical approach for achieving this in the short-to-medium term is better water management in the upper and
\end{abstract}


middle river basins, and that a more rational basis for allocating water to meet the needs of all users is urgently required. The paper describes a real-time water resources management model for the Syr Darya river that has been designed for sustainable planning and management of the water resources to meet the needs of all riparian users. The power and limitations of such models in relation to effective management of the water resources of the Aral Basin are discussed.

\section{RESUME}

La crise environnementale de la mer Aral est due à une mauvaise gestion des bassins versants de l'Amu Darya et du Syr Darya. La quasi-totalité du débit alimente d'une part les réseaux d'irrigation à l'amont et au milieu des bassins versants et d'autre part les réseaux de transfert entre bassins; une dernière partie du débit est perdue par évaporation ou infiltration depuis les réservoirs et les canaux. Il est dès lors nécessaire de recréer un flux suffisant qui parvienne jusqu'à l'aval du delta. Le présent article montre que pour atteindre cet objectif à court ou moyen terme, il faut une meilleure gestion des eaux à l'amont et au milieu des bassins; il faut également repenser le distribution des eaux afin que tous les usages puissent satisfaire leurs besoins. L'article présente un logiciel permettant de modéliser au cours du temps l'utilisation des ressources en eau du Syr Darya; ce modèle a été élaboré en vue d'une planification et d'une gestion durable de la ressource en eau pour répondre aux différents besoins. L'efficacité de tels modèles est ici évaluée en fonction de l'objectif poursuivi dans le cas du bassin versant de l'Aral.

Key Words: Aral Sea, River Basin Planning, Water Resources Management. Mots Clefs: Mer d'Aral, gestion à l'échelle du basin versant, gestion des ressources en eau. 


\section{INTRODUCTION}

The Aral Sea is fed by two great rivers: the Amu Darya, with a mean annual flow of 62 to 72 $\mathrm{km}^{3} \mathrm{y}^{-1}$, and the Syr Darya, with a mean annual flow of 37 to $40 \mathrm{~km}^{3} \mathrm{y}^{-1}$. Unfortunately since the 1960s there has been a complete collapse in the environment of the lower river basins, with the once-productive wetlands and much of the Aral Sea bed itself drying and becoming a saline desert. The collapse was brought about by over-abstraction of water for vast irrigation schemes and by storage and management losses from hydroelectric reservoirs in the six riparian states of Afghanistan, Tadzhikistan, Kyrghyzstan, Uzbekistan, Turkmenistan and Kazakhstan. The causes of the dying of the sea and the complete degradation of these once-great deltas have been well documented elsewhere (Centre for International Projects, 1991; Micklin, 1994; Tanton et al., 1999).

Not only have the Aral Sea and its deltas been destroyed, but the newly irrigated land itself is also under threat from salinisation and waterlogging. Despite the fact that most of this land has only been irrigated for the past 40 years, nearly 8 million hectares corresponding to some $50 \%$ of the irrigated land is already affected to some degree by salinity and waterlogging.

The environmental collapse of the two great deltas of the Amu and Syr Darya and of the Aral Sea itself is a direct result of over-exploitation of the rivers, and it is clear that any form of rejuvenation will depend crucially upon securing a major increase in the quantity of minimallypolluted water that can be delivered to the deltas annually. The water will then need effective management to ensure that flows in the deltas are restored to historic levels.

The riparian states have established an institutional framework to implement a recovery programme, known as the Aral Sea Basin Program (World Bank, 1998). The objectives of the programme are to: 
- Stabilise the environment of the Aral Sea Basin

- Rehabilitate the disaster zone around the sea

- Improve the management of the international waters of the basin

- Strengthen the capacities of the regional institutions to plan and implement the above programmes

Within the Aral Sea Basin Program, international agreements have also been signed between the riparian states defining four main principles for managing the water resources of the basin:

- Priority will be given to existing water users

- The right of each basin state to an equitable and reasonable share of the available water resources will be observed

- The sovereignty of each state over its national resources and its share of transboundary water resources is assured

- New activities should not be initiated that reduce the shared water resource

It is not immediately obvious, however, how these management principles relate to the programme objectives, and a great deal will depend on the interpretation of the short phrases that form the four main principles. At present it is far from clear, for instance, whether the rights of existing water users include the rights of riparian users in the lower basin; and whether an 'equitable and reasonable share' is the amount of water that is needed to irrigate an hectare of land, or the amount of water that is actually taken to irrigate it. In sharing out the basin's water resources, will the quality of the water in the lower reaches of the river be guaranteed, and will adequate provision be made to allow sufficient drainage to maintain a salt balance? Clearly there are many issues that need to be resolved before the objectives of the Aral Sea Basin Program can be achieved.

It is also evident that any plan which is developed for the rehabilitation of the region will 
need to encompass the implementation of an effective, fair and lasting agreement for watersharing between all riparian groups and nations (Khamidov et al., 1999). This agreement must take into account the salt balance of the basin and must recognise the priority of the riparian users in the lower basin, not just the needs of the more recently developed irrigation schemes. The development, agreement and implementation of such a plan will depend critically upon an effective means of supporting a rational decision-making process for allocation of water for consumptive use, at the international river basin, national and local levels.

There are many technical solutions that could be implemented to improve water use efficiency and increase production in the large irrigation schemes, and at the same time make more water available for the riparian users in the lower basin. Unfortunately it is estimated that to rehabilitate the irrigation and drainage system alone would cost between 15 and 20 billion US dollars and would take many decades to achieve. Because of the sheer size of the problem and the economic collapse of the riparian states, it is likely that only a small fraction of the total area will be rehabilitated in the short to medium term, and that this will be of little significance in mitigating the environmental disaster of the lower delta.

It is generally agreed that, in the short to medium term, the only practical solution is therefore better management of the water resources of the rivers and their reservoirs. The issues that need to be resolved before better management can be brought about are many, but the basis of good water resource management is a sound understanding of the system and its resources to enable planners to make their decisions on a rational basis. The key to obtaining a better understanding is the availability of a reliable water resource database and of effective water resource management simulation models that can be used by planners to gain a clear understanding of the system and of the options available to them. 
A number of different types of water resource simulation models are needed if this complex system is to be managed. Large-scale models linking climatic effects with the regional water balance can provide an idea of the overall water balance for the rivers and the sea (Ferrari et al., 1999; Small and Sloan, 1999). Multi-objective models allow optimisation of overall water distribution and the balance between irrigation and hydropower generation, or consideration of the economic and environmental consequences of policy choices (McKinney and Cai, 1997a and 1997b; McKinney et al., 1999). At an operational scale, hydraulic models of the rivers and main canals are needed to identify bottlenecks preventing effective use. Water scheduling models are required for the main irrigation canals to ensure that water is not wasted by poor management. Interactive water resource planning and management models are also needed for optimising the available water resources of the basin. (Raskin et al., 1992). This paper describes one such interactive water resources model that has been developed for the Syr Darya basin, AralMod.

\section{An Aral Basin Water Management Model: AralMod}

The rivers and the main irrigated areas of the Aral Basin are shown in Figure 1.

\section{Conceptual basis of the model}

The core of the model is a real-time mass balance river/reservoir model for the Syr Darya. The model calculates the overall water balance for the river, the main reservoirs and the irrigation massifs, every six days for up to a 20 -year period. It calculates the water balance for the reservoirs and for the seven river sections: Fergana valley, Toktogul to Kayrakumskoye, Chardara to Arys River, Turkestan, Kzyl Orda, Dzhusalyi, and Kazalinsk, and finally the Aral Sea itself. 
For each river/reservoir section the model takes account of inflow from the main river, side rivers and drains; calculated evaporative losses based on regional monthly climatic conditions; seepage losses; irrigation offtake and, in the case of reservoirs, the set discharges. It calculates the net river outflow from each reach or reservoir. The model includes Toktogul, Kayrakkumskoye and Chardara reservoirs and will display changes in storage for up to a 20year period. Other smaller but significant reservoirs have yet to be added to the model and are currently only described in terms of mean monthly discharge, but will replaced as data becomes available.

Monthly river inflow into the base model is for the period 1975 - 1994 for Toktogul reservoir and for discharge from the Arys and Keles rivers. In the present model data for inflows from all other rivers are monthly averages, but this can be upgraded when data becomes available.

The model assumes that the North Aral Sea is isolated from the South Aral Sea by the Aklak dam, and for every six days calculates the flow into the North Aral Sea. The model calculates evaporation losses from the Sea and takes account of mean monthly rainfall: above a given level (which can be selected), excess water is discharged to the Southern Sea. The model displays changes in the level, volume and area of the Sea over time.

Irrigation water requirements and potential evapotranspiration for all irrigation massifs are calculated every six days. The model can withdraw water from the river for irrigation schemes based either on the calculated crop water demand or on pre-set discharges determined by gate settings. Field and canal efficiencies can be set if known, but otherwise irrigation efficiencies are calculated.

The model has been designed as a water management tool to aid planning and management of the overall water resources of the Syr Darya river basin and the North Aral Sea. The model 
when calibrated will enable planners to study the impact of different water and irrigation management practices on the overall water resources of the river basin.

The model will over a 20-year period:

- Predict the downstream availability of water and changes in Aral Sea levels that will occur if changes are made to irrigation practices, drainage return flows, hydropower generation, and dam discharges.

- Indicate annual changes in dam storage that will result from different seasonal water releases for power generation and/or in meeting irrigation demand.

- Indicate the consumptive use in each country and in each of the major irrigation schemes.

- Show crop water needs for all crops or cropping patterns throughout the year and compute seasonal water demand for all irrigated areas.

- Predict irrigation efficiency for all irrigation schemes.

- Indicate where water is being wasted.

- Predict changes in volume of water in the North Aral Sea

The model can be used to:

- Study the likely impact of possible international water sharing agreements on the usefulness of the seasonal availability of the water for the riparian nations and for the North Aral Sea and the deltas.

- Study the effects of dam operating conditions on the availability and wastage of water.

- Study the effect of improved water management practices and rehabilitation projects on the availability of water in the lower Aral basin. 
- Establish which proposed irrigation rehabilitation, water management or drainage schemes would result in improved discharge to the Aral Sea.

- Study the effect of growing different crops on the availability of water in the lower basin.

- Study the effect of different power generation strategies on the availability of water for irrigation and develop systems for the operation of downstream reservoirs to optimise the use of water resources for the benefit of irrigation and the lower Aral basin.

- Establish where and how much water is wasted and where water can be saved.

\section{Description of the Program}

The program is written in Visual Basic, runs in Windows 95/98/NT, and requires about $25 \mathrm{Mb}$ of free disk space. Copies can be obtained from the authors.

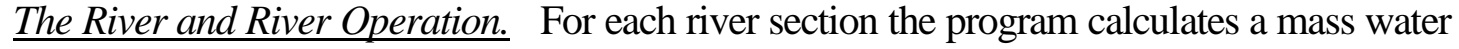
balance from:

$$
W_{\text {Out }}=W_{\text {In }}+W_{G}+W_{D}-W_{\text {Irr }}-W_{\text {RS }}-W_{E}-W_{\text {Ind }}
$$

Where

$$
\begin{array}{ll}
\mathbf{W}_{\text {Out }}=\text { Outflow from river section } & \mathbf{W}_{\text {In }}=\text { Inflow into river section } \\
\mathbf{W}_{\mathbf{G}}=\text { Groundwater Inflow } & \mathbf{W}_{\mathbf{D}}=\text { Drainage return flow } \\
\mathbf{W}_{\text {Irr }}=\text { Irrigation take off } & \mathbf{W}_{\mathbf{R S}}=\text { Seepage loss } \\
\mathbf{W}_{\mathbf{E}}=\text { Calculated evaporation loss } & \mathbf{W}_{\text {Ind }}=\text { Industry }
\end{array}
$$

Reservoir and Reservoir Operation. The model calculates the water balance in the reservoirs every six days as follows:

$$
\mathbf{W}_{S}=\mathbf{W}_{C}+\mathbf{W}_{R I}+\mathbf{W}_{R}-\mathbf{W}_{D}-\mathbf{W}_{I}-\mathbf{W}_{E}
$$

Where 


$$
\begin{aligned}
& \mathbf{W}_{S}=\text { Stored Volume in Reservoir } \quad \mathbf{W}_{C}=\text { Current Volume in Reservoir } \\
& \mathbf{W}_{\boldsymbol{R}}=\text { River Inflow } \\
& \mathbf{W}_{\boldsymbol{R}}=\text { Rain } \\
& \mathbf{W}_{\boldsymbol{E}}=\text { Direct Irrigation from reservoir } \quad \mathbf{W}_{D}=\text { Dam Discharge } \\
& * \text { Calculated every six days using Penman-Montieth } .
\end{aligned}
$$

Monthly discharges from the reservoirs can be set (in $\mathrm{m} / \mathrm{s}$ ). If the level in the reservoirs exceeds the crest of the spillway, water is discharged to the river below, except in the case of Chardara reservoir where it is discharged to the Arnasay depression.

Calculation of Irrigation Water Requirements. Crop potential evapotranspiration. The program calculates the potential crop evapotranspiration for six-day intervals for each of the irrigated crops in each of the irrigation massifs. Crop water demand is calculated for each sixday period from mean monthly regional climatic data using the method of Penman as modified by Montieth (Penman, 1948; Monteith, 1981). Default planting dates for crops for each region are those given in the WARMIS database (WARMIS, 1996) but can be readily changed by the user in the input data pages. Total crop water demand for each crop in a massif is the potential crop evapotranspiration minus the mean precipitation for the same period.

Irrigation Water Requirements. The program calculates the total irrigation water requirements for each irrigated massif from:

$$
W_{i}=\frac{A_{i}}{F_{i} T_{i}} \sum_{j=1}^{N}\left(E t_{\text {crop }}-R_{i}\right) C_{j}
$$

Where

$$
\begin{aligned}
& \mathbf{W}_{\mathbf{i}}=\text { 6-day irrigation water requirements for massif } \mathbf{i} \\
& \boldsymbol{A}_{\boldsymbol{i}}=\text { Total irrigated area of irrigated massif } \\
& \boldsymbol{E}_{\boldsymbol{t}_{\text {cropj }}} \quad \text { = 6-day evapotranspiration per hectare for crop j. }
\end{aligned}
$$




$$
\begin{array}{ll}
\boldsymbol{j}=\text { crop type } & \boldsymbol{N}=\text { number of different crop types } \\
\boldsymbol{C}_{\boldsymbol{j}}=\% \text { Total area planted to a crop } & \boldsymbol{F}_{\boldsymbol{i}}=\text { Field efficiency } \% \\
\mathbf{T}_{\mathbf{i}}=\text { Canal Transmission efficiency } \% & \mathbf{R}_{\mathbf{I}}=\text { Precipitation in the } 6 \text { day period } .
\end{array}
$$

Crops and Cropping Patterns. The time of planting and harvest of each crop together with the percentage area planted to each crop for each irrigation massif are set at default values but can also be user-defined to reflect present cropping practices

Irrigation efficiency. No water has been allowed for salt leaching as normal practical irrigation efficiencies will provide more than sufficient water for effective leaching. Default infield irrigation efficiency has been set at levels suggested in the WARMIS database, typically $65 \%$ to $75 \%$, but all values can be reset and user defined (see Figure 2).

The overall average canal transmission efficiency has been set at default values of $65 \%$ to $80 \%$ based on data from the WARMIS database, but these can be user-defined for each irrigation massif. This aspect of the program urgently needs calibration to enable it to reflect real field conditions.

Seepage losses and drainage return flows. The Fergana valley is a hydrogeologically closed valley and all irrigation and canal seepage water that enters the groundwater must either flow into the river system or evaporate from shallow groundwater. Within the valley only a small percentage of the floor has groundwater within 1.5 meters of the surface and is not irrigated. It has therefore been assumed for the default setting in the model that $90 \%$ of the seepage water either reduces $\mathrm{Et}_{\text {crop }}$ or will flow in the groundwater back to the river over a 12-month period. Alternatively, drainage return flow can be user defined if required.

Between Kayrakkumskoye and Chardara Reservoir topographic features mean that most of the groundwater flow from the irrigated massifs does not return to the river but flows to a 
shallow saline manmade lake in the Arnasay depression. Shortly below Chardara reservoir the river becomes a raised river and, once water has been abstracted for irrigation, drainage is generally away from the river unless manmade drainage systems return it. Seepage losses are therefore not returned below Chardara unless artificial drainage systems are known to exist. The program does however allow the operator to return drainage water to the river and thus to take account of both new and existing drainage schemes.

Irrigation Water Management. Irrigation offtake from the river can either be set on the basis of calculated crop water requirements and irrigation efficiencies, or to pre-set monthly canal offtakes. The default monthly pre-set offtakes for the irrigation massifs were taken from the WARMIS database.

\section{Climatic Data and Hydrological Data.}

Climate. Mean monthly climatic data for sunshine hours (h), daily wind run (km/day), $\mathrm{T}_{\max }$ and $\mathrm{T}_{\min }$, relative humidity $(\%)$, and monthly total rainfall $(\mathrm{mm})$ for each of the seven river sections and for the Aral Sea were taken from meteorological stations at Fergana, Syr Darya, Chardara, Turkestan, Kzyl Orda, Dzhusaliy, Kazalinsk, and Aral Sea (Aralsk).

River Inflow. Monthly discharges were taken from gauging station data of the Keles and Arys rivers and from monthly inflow into the Toktogul Reservoir from 1975 to 1994 . All other river mean monthly inflow data was taken from the WARMIS database. This later data set needs further refinement before it can be reliably used for running in real time.

Surface area and volume of the North Aral Sea. The relationship between surface area, height of surface above mean sea level and volume of the small North Aral Sea after construction of the proposed Aklak dam was taken from the Syr Darya Control and Delta Development Project (Italconsult \& Electroconsult, 1995). 
Crop Planting dates and duration of cropping. The default data were taken from the WARMIS database.

Help. The program can be run in English or Russian and has a comprehensive drop-down help menu for all functions as well as a detailed program description.

Data Output. Output data can be presented in tables and/or in summary graphical format. Examples of graphical output data are given in Figure 3 and Figure 4.

\section{Limitations of the model and future developments}

This program together with its core algorithms provides a powerful tool for developing environmentally sound water management strategies for the Syr Darya river. The full capacity of the program will only be developed, however, when more real-time data is entered for the smaller river inflows of the upper catchment and when the model is correctly calibrated to present irrigation operating conditions and cropping patterns. The model's performance is mainly limited by the availability and quality of data. The main deficiencies are given below.

- At present real-time hydrological data only exists for the main river inflows, while other inflows are monthly mean values only. The annual performance of the model will be improved with this additional data.

- Water retention time in each of the river sections needs verification.

- Seasonal groundwater flows can be added as more data becomes available.

- Better data is needed on river seepage and inflow rates in different reaches.

- Available data is very unreliable.

The model has the potential to provide a powerful planning support tool but development and testing has highlighted the need for better data. Additional data will be included as it becomes 
available, but it is clear that until it does the performance and value of all management models will be severely restricted.

\section{DISCUSSION AND CONCLUSIONS}

Results from operating the program in default mode, using official WARMIS statistics (WARMIS, 1996 and 1997) indicate that on average irrigation efficiencies are extremely low, less than $20 \%$ for some irrigation schemes. Clearly water is either being used extremely inefficiently, or the river offtake data or cropped area data are unreliable, or possibly both. Sometimes the large differences between predicted crop water demand and canal discharges are consistent throughout the growing season and could be accounted for by high seepage losses; while in other cases the difference is much more serious at certain times of year, which would result in large drainage losses. The model does indicate however that with the existing mode of water management, as shown by official statistics, the amount of water passing to the sea will be inadequate to reclaim the Northern Aral Sea in the long term.

At the present time there are international agreements on the sharing of water between the riparian states. When conflicts arise, they tend to be solved on an ad hoc basis for the benefit of consumers in the upper and middle basin, with little regard for how they might affect the lower basin. If water resource management programs are to be used to support lasting international agreements and to provide a rational basis for allocating water to different schemes, they will depend critically on a reliable, mutually-agreed source of data. It is the opinion of the authors that, while the WARMIS database has gone a long way towards bringing the necessary data together, there is still a great deal of work to be done in checking the reliability of the data. Cropping practices have changed dramatically in the past ten years, as has the cropped area. Unfortunately there is no effective mechanism for collecting this data, and it is therefore 
essential to instigate an effective data collection system. Digital satellite data can be used, reliably and very cost-effectively, to obtain and update data on cropping patterns and cropped areas in each irrigation scheme, as well on the area requiring water for environmental needs. Such data would be available for everyone to verify and could form a sound technical basis for setting crop water needs.

The discharge curves for all significant river offtakes and drains need recalibrating and a regular reliable monitoring system needs to be re-instigated to ensure a reliable source of data. In addition all major gauging stations need to be automated. To do this effectively is a major task and will be difficult in the present socio-economic conditions, but without such data the potential of sophisticated water resource management tools for helping to resolve the Aral crisis cannot be realised.

Modern computerised water resource management tools such as that proposed by Raskin et al. (1992) and the one proposed above can be very powerful planning tools. Unfortunately in the case of the Aral basin realistic model operation cannot be achieved nor will the robustness of models be tested until better data are available. More complex economic models and optimisation programs, which are based on the results taken from these systems, are also unlikely to prove of any value until better supporting information is obtained (McKinney et al., 1999).

At the present time, therefore, it is only possible to use these models to help increase our understanding of the issues, and to highlight some of the major problems. These are of course useful functions, and can indicate where resources need to be deployed, but the full power of such approaches for optimising water resource utilisation in the Aral basin and identifying practical, cost-effective ways out of the crisis will depend on the provision of adequate data. 
This work was carried out with the financial support of BG Group and the EU's INCOCopernicus Programme.

\section{REFERENCES}

Ferrari MR, Miller JR, Russell GL. 1999. Modeling the effect of wetlands, flooding, and irrigation on river flow: Application to the Aral Sea. Water Resources Research 35: (6) pp.1869-1876.

Italconsult \& Electroconsult. 1995. Syr Darya Control and Delta Development Project. Report for the Government of the Republic of Kazakhstan for the International Bank for Reconstruction and Development. Italconsult. Italy.

Khamidov MKh, Kipshakbayev NK, Navruzov S, Yusupov B. 1999. Assessment of the current situation in the Syr Darya basin water resources use. Report prepared for US Agency for International Development, Environmental Policies and Institutions for Central Asia (EPIC) Program, Almaty, Kazakhstan.

McKinney DC and Cai X. 1997a. Multiobjective Water Resource Allocation Model for Toktogul Reservoir, Technical Report, US Agency for International Development, Environmental Policy and Technology Project, Central Asia Regional EPT Office, Almaty, Kazakhstan.

McKinney DC and Cai X. 1997b. Multi-objective Optimization Model for Water Allocation in the Aral Sea Basin, Proc. 3rd Joint USA/CIS Joint Conference on Environmental Hydrology and Hydrogeology, pp. 44-48, American Institute of Hydrology, St. Paul MN.

McKinney DC, Cai X, Lasdon LS. 1999. Integrated Water Resources Management Model for the Syr Darya Basin, Technical Report, US Agency for International Development, Environmental Policies and Institutions for Central Asia (EPIC) Program, Almaty, Kazakhstan.

Micklin PP. 1994. The Aral Sea Problem. Proc. Inst. Civ. Eng. 102, Aug 114-121.

Monteith JL. 1981. Evaporation and surface temperature. Quart. J. Roy. Meteorol. Soc. 107: 1-27.

Penman HL. 1948. Natural evaporation from open water, bare soil and grass. Proc. Roy. Soc. London, A193, 120146.

Raskin P, Hansen E, Zhu Z, Stavisky D. 1992. Simulation of water-supply and demand in the Aral Sea region. Water International 17: (2), pp.55-67

Small EE, Sloan LC, Hostetler S Giorgi F. 1999. Simulating the water balance of the Aral Sea with a coupled regional climate-lake model. Journal of Geophysical Research-Atmospheres 104: (D6) pp.6583-6602 
Tanton TW and Heaven S. 1999. The Worsening of the Aral Crisis: Can there be a solution? J WATER RES PLASCE 125: (6) 363-368.

WARMIS. 1996. WARMIS database. SANIIRI, Tashkent

WARMIS. 1997. Formulation and Analysis of Regional Strategies on Land and Water Resources. European Union WARMIS project report (July). Tashkent.

WORLD BANK. 1998. Aral Sea Basin Program Project Document

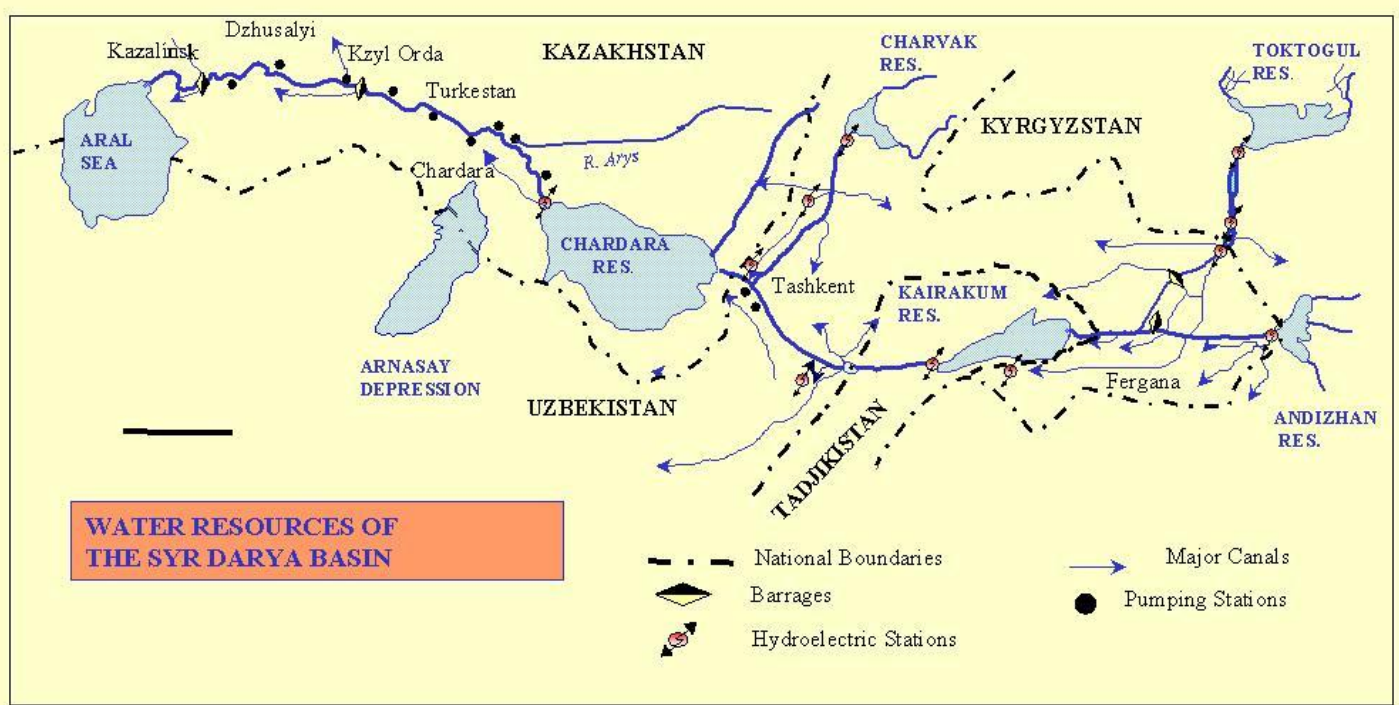




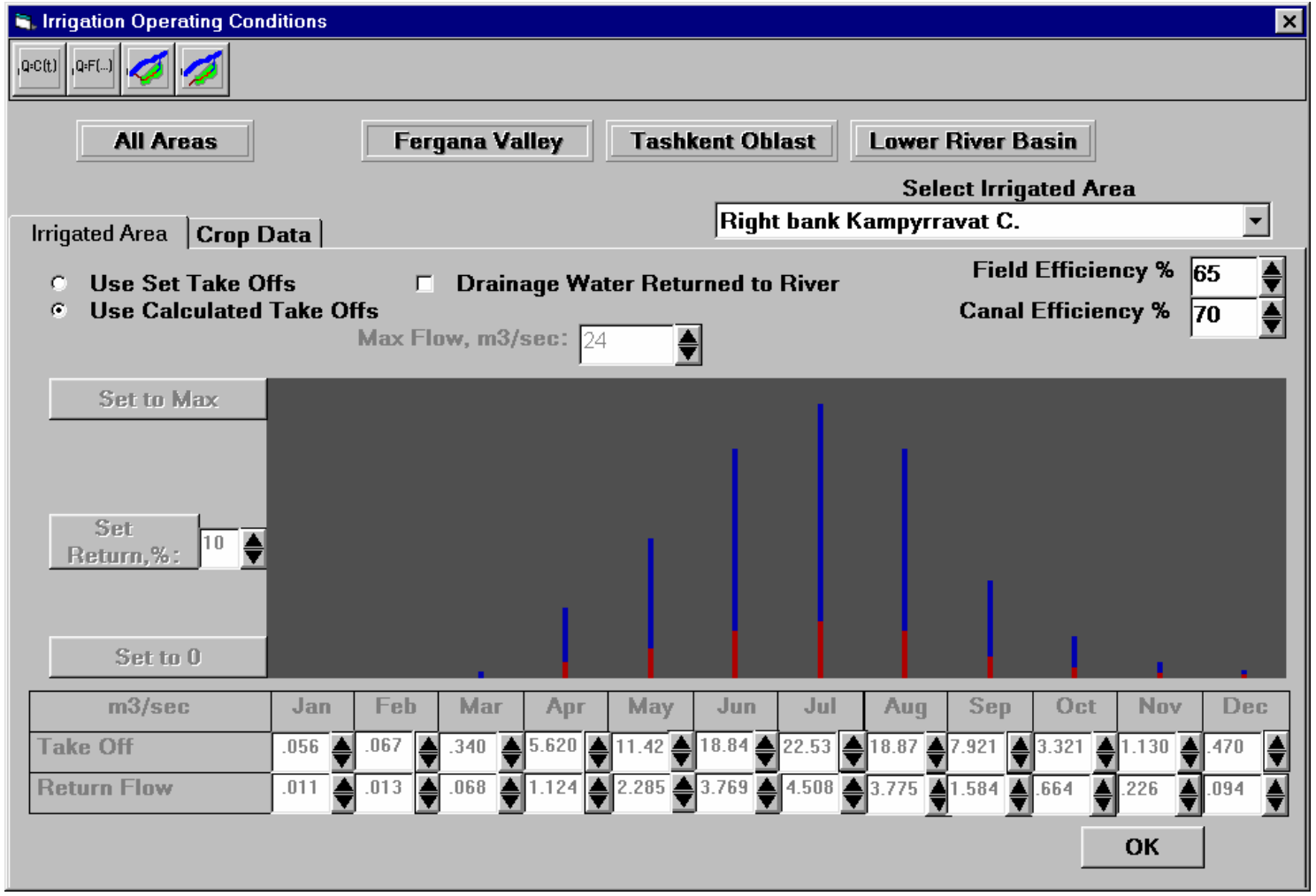




\section{Aral Sea Output}
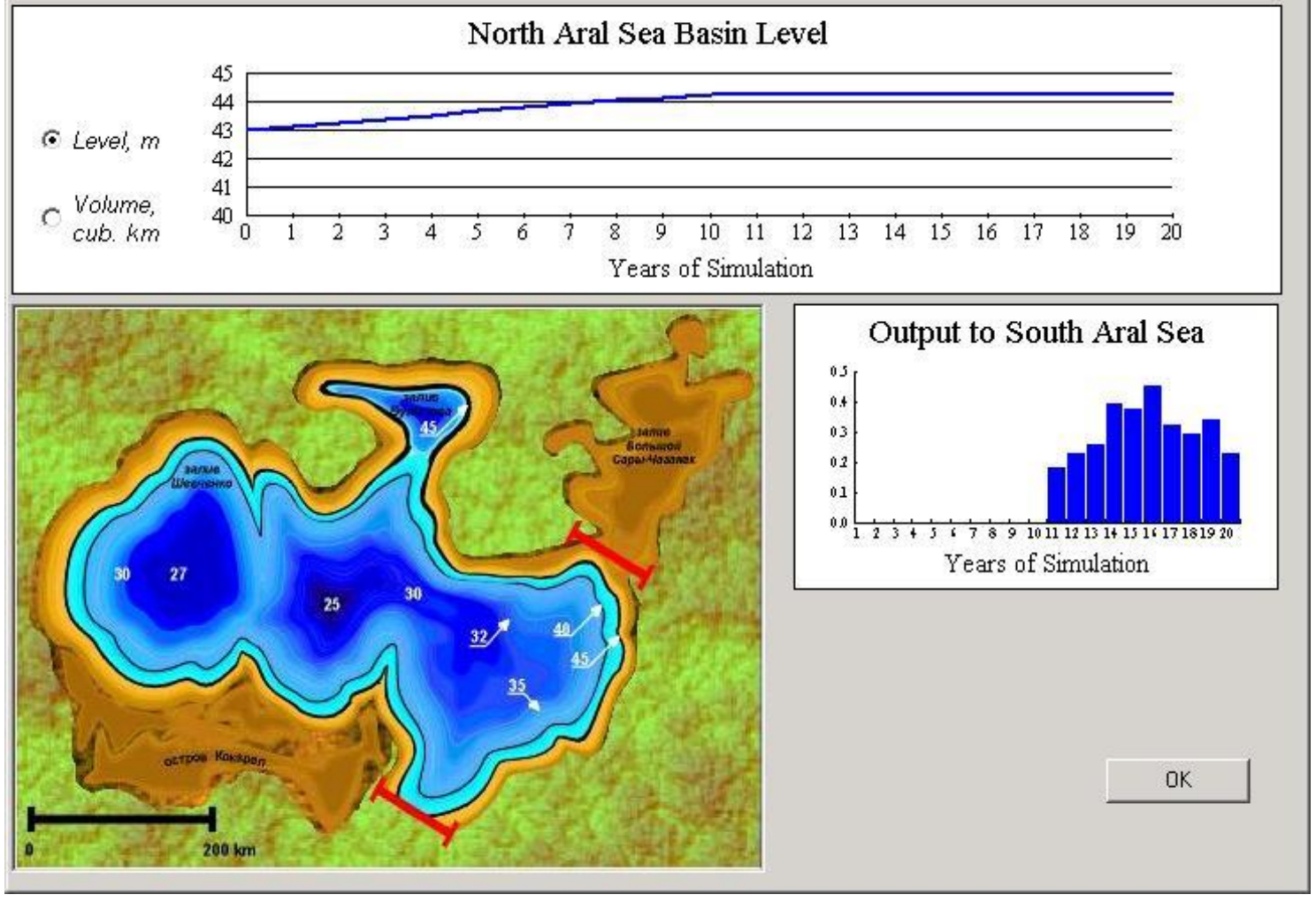